\title{
Rhetorical Move Structure of Literature Book Prefaces in English and Persian
}

\author{
Hoda Mohsenzadeh \\ Department of Foreign Languages \\ Kharazmi University, Tehran, Iran \\ Email: Mohsenzadehn@yahoo.com
}

\section{Doi: 10.5901/mjss.2013.v4n4p317}

\begin{abstract}
Genre analysis dealing with how people use language in particular discourse communities has become the focus of research in the last two decades (Tahririan \& Jalilifar, 2004). Considering the importance attributed to genre studies, the present research was conducted to report on a move analysis of literature book prefaces in English and Persian. The obligatory moves in the English corpus were found to be: General statement about or general description of the book/ The purpose/ Information about the chapters or other volumes and the obligatory moves in Persian prefaces were found to be: the significance of the topic/ general explanation about the topic/ Thanking others and expressing gratitude to people who have helped in the process of writing the book (acknowledgements).
\end{abstract}

Key terms: Genre, genre analysis, move

\section{Introduction}

Since 1990s, when for the first time Swales identified communicative moves of the genre of research article introductions and presented his Create A Research Space (CARS) model, there has been an increasing attention to the structure of other academic genres. This interest has its roots in the international role of English in scientific communication and the rapid growth of the number of non-native researchers who need to learn conventions of academic writing in order to join international academic discourse communities. In Dudley-Evans' (1986) words: "This interest has been motivated by pedagogical concerns, in particular the need to provide satisfactory models and descriptions of academic and scientific texts to enhance the ability of non-native students to understand and produce them" (p. 136).

After Swales' (1990) work, many other researchers tried to apply his suggested framework to other genres; research articles (RAs), review articles, editorials, book reviews, and letters to the editor are some of these analyzed genres among many others. In the present research, the macro-structure of the genre of preface is the focus. Like other studies within the genre approach to language description, it attempts to explain how members of a particular discourse community achieve their communicative purposes. The general aim of this genre analysis, in fact, according to Henry and Roseberry (2001) is "to identify the moves and strategies of a genre" (p. 154).

\section{Literature Review}

Genre analysis has followed three main traditions including the English for Specific Purposes (ESP) approach in which genre studies have been seriously emphasized (Toledo, 2005). The ESP approach to genre analysis was introduced by Swales in 1990s with his seminal work on research article introductions. Within this approach, whereby learners' and teachers' attention are drawn to communicative purposes of texts rather than their surface features (Hüttner, Smith, \& Mehlmauer-Larcher, 2009), different genre studies have been carried out. Researchers have focused on various academic and non-academic genres and have tried to examine either their macro-structure in terms of their constituting 'moves or steps' or their common lexico-grammatical features. Among many others, some of the academic genres examined by researchers up to now include different sections of research articles: abstracts (Cross \& Oppenheim, 2005; Hyland, 2000; Lores, 2004; Martín-Martín, 2003), introductions (Habibi, 2008; Hirano, 2009; Ozturk, 2007; Rubio, 2011), discussions (Atai \& Fallah, 2005; Biria \& Tahririan, 1997; Nwugo, 1997; Peacock, 2002), different parts of theses and dissertations such as acknowledgements (Golpour Lasaky, 2011; Hyland, 2004) and the literature review chapter (Kwan, 2006), the genre of book reviews (Moreno \& Saurez, 2008), book blurb (Valor, 2005), conference proposals (Halleck \& Connor, 2006), and syllabus (Afros \& Schryer, 2009). In most of these studies, researchers have tried to examine the 
generic structure of the aforementioned genres in order to provide a detailed picture of their constituting discourse elements. Despite all these attempts, it seems that the existing literature suffers from a gap in genre studies which is related to the fact that introductory genres such as book prefaces have been left untouched. Following previous scholars, especially Swales (1990), this research is conducted within the ESP approach; the researcher intends to investigate the genre of book prefaces which despite its importance has been the focus of little empirical research. The area of concern in this analysis is, therefore, to contribute to the growing body of research in the area of genre analysis by occupying the aforementioned niche and examining a genre which has not received the attention it deserves. So as was mentioned by Henry (2007), like other genre studies of ESP approach, the researcher aims at identifying obligatory and optional moves.

\section{The purpose of the study}

Nowadays, genre is believed to be a kind of sociolinguistic activity in which members of a particular community take part. From a language teaching perspective, too, a genre is considered as consisting of a series of moves. While prefaces are one of the important parts that the majority of books include, there has been little investigation on their move structure, Prefaces are important because they help the reader to have an overview of the book, to get some information about the different parts of it, and thus to decide which parts correspond to their purpose in mind and worth reading. The significance of the present study lies in the fact that it can show how much flexibility the genre allows regarding obligatory and optional moves. through which awareness of discipline-specific move structure can be increased and also a discipline-specific move structure model can be prepared.

This study through which awareness of discipline-specific move structure can be increased is to shed light on:

a- The generic structure of both Persian and English literature book prefaces

b- The similarities and differences in the move structure of this genre in these two languages

\section{Research Question}

This text- based, exploratory study serves mainly to examine the moves of book prefaces written by authors in the two languages of Persian and English. More specifically this study strives to answer the following question:

How are Persian and English literature books different in terms of the moves included in their preface sections?

\section{Methodology}

\subsection{The corpus}

The corpus of the study was made of 40 literature book prefaces, twenty of which were in English and twenty others in Persian. The year of publication for English books varied from 1965 to 2006 and for Persian books from 1348 to 1386 . In English books, the number of pages dedicated to preface varied from 1 to 4 and in Persian books from 1 to 5 pages. In order to have a more homogenous corpus, all prefaces that were translated versions were omitted.

\subsection{Analytical Framework}

The analytical approach chosen for this study was that of genre analysis following Swales (1990) and Bhatia (1993).

\subsection{Procedure}

Having selected the corpus, the researcher analyzed each preface separately and identified the moves. In this study, move was defined as "discourse or rhetorical unit that performs a coherent communicative function in a written or spoken discourse." (Swales, 2004, p. 229). To identify and code the moves, as suggested by Ansary and Babaii (2005), the researcher tried to use linguistic clues that authors usually employ as well as boundary markers and typographical cues. Besides, the researcher tried to identify moves not only according to the physical clues and identification of key words but also according to the content and communicative purpose each segment fulfilled. The cut-off frequency of $60 \%$ of occurrence was also established to determine obligatory and optional moves. In order to eliminate analyst bias and to establish inter-coder agreement, $25 \%$ of the data were randomly chosen and analyzed by a second rater. 


\section{Results}

Moves: (English books)

1- General statement or general description of the book:

(General statement) Example1: In recent years, women have been increasingly associated with the Arthurian tradition. From the historical retellings of the legendary stories to the original re-workings of them, from the versions set in Arthur's day to those set in modern times, from fantasy and science fiction to mystery and children's literature, contemporary Arthurian novels by women have garnered critical attention and gained popular acclaim.

(General description) Example 2: This book defines and discusses terms, critical theories and movements, and points of view that are commonly used to classify, analyze, interpret, and write the history of works of literature.

2- The significance of the book:

Example1: Given the amount and the scope of recent popular Arthurian women's fiction, it is surprising that there is so little awareness among readers and scholars alike of the significant earlier and ongoing tradition of Arthurian literature by women.

Example2: Large areas of drama history have been left untouched.

3- The purpose:

Example1: This series aims to disseminate the best of recent criticism and to show that it is possible to reread the canonical texts of literature in new and challenging ways.

Example2: The aim, here, is to provide clear, well- illustrated accounts of the full range of terminology currently in use, and to evolve histories of its changing usage.

Example3: The book seeks to give the student a sufficient grasp of the nature and variety of literary works...

4- The type of audience:

Example1: Although the book is intended primarily for students in schools and universities, I hope that it will help anyone interested in literature...

Example2: Literature, sound, and sense is intended for the student who is beginning a serious study of imaginative literature.

Example3: This book has been written for those who are interested in reading about drama for the first time, and who want to know something more of the meaning and purpose of drama, and of its development in other countries.

5- Description of content, book chapters and other volumes of the book:

Example1: Each section begins with a simple discussion of the element of the form and is illustrated, throughout, by carefully chosen stories, poems, and plays. Each section also includes additional selections for further reading.

Example2: For students who are preparing for examinations in English literature, I have included exploratory exercises at the end of each chapter. Chapter 8 contains practical advice for students preparing for "unseen" or" practical criticism" papers ...

Example3: A Glossary of Literary Terms consists of succinct essays in the alphabetic order of the title word or phrase. Terms that are related but subsidiary, or that designate subclasses, are treated under the title heading of the primary or generic term; also words that are often used in conjunction or as mutually defining contraries are discussed in the same entry.

Example4: Each volume in the series will attempt an objective position of significant developments in its field up to the present as well as an account of its author's own views of the matter.

6- More explanation about the book:

Example1: This book, then, is an introduction to both literary theory and a history of theory. But it is a history in which what has become historical is simultaneously actual...

Example2: The series is designed so that the books in it can be used independently of the others in the series. Many intermediate or advanced learners may be able to begin with the third or fourth books....

$>$ Less frequent moves: hope expression, suggestions, and acknowledgement.

- Hope expression:

Example1: The enterprising reader will, I hope, forgive me if he has to use his dictionaries as much as I did. 
Example2: It is to be hoped that this book will help those who are keen to develop national drama to realize the important part which drama can play in a civilized society, and to take inspiration and encouragement from the efforts and achievements of other lands where dramatic traditions have been established.

- Suggestions:

Example: All I can do is to ask the reader who reads to the end to re-read Part One and to resist thinking of all the names and novels I have decided or forgotten to include.

- Acknowledgements:

Example: It would be impossible to express all indebtedness, but for personal advice, criticism, and assistance I wish especially to thank my wife, Catherine Perrine ...

Table 1: Frequency and percentage of identified moves in English book prefaces

\begin{tabular}{|cl|c|c|}
\hline \multicolumn{1}{|c|}{ Move } & Frequency & Percentage \\
\hline $1-$ & General statement/ description & 15 & $\% 75$ \\
\hline $2-$ & The significance & 8 & $\% 40$ \\
\hline $3-$ & The purpose & 18 & $\% 90$ \\
\hline $4-$ & Type of reader & 11 & $\% 55$ \\
\hline $5-$ & 12 & $\% 60$ \\
& Information about the chapters or other \\
volumes & 11 & $\% 55$ \\
\hline $6-$ & More explanation & 11 & \\
\hline
\end{tabular}

As table 1 displays, the following are obligatory moves in English literature book prefaces. (The percentage of their appearance is more than 60):

1- General statement about or general description of the book: A little description of the book in general lines.

2- $\quad$ The purpose: A little explanation about what the readers will gain if they read the book.

3- Information about the chapters or other volumes

According to this table, the rest of the identified moves i.e. the significance, the type of reader, information about the chapters or other volumes and more explanation are optional.

\section{Moves: (Persian books)}

1- The Significance:

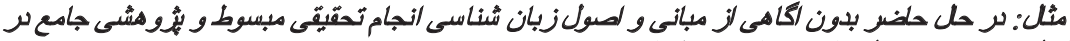

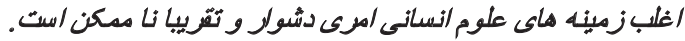

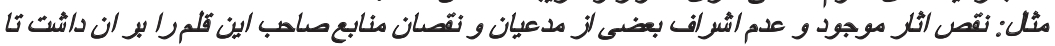



2- The Purpose:

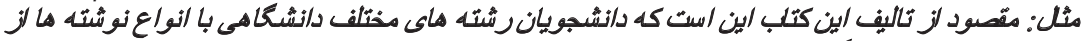

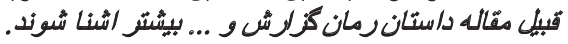

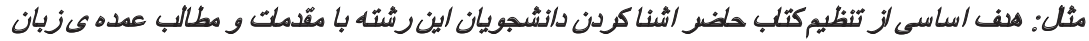

3- The type of reader:

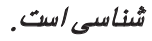

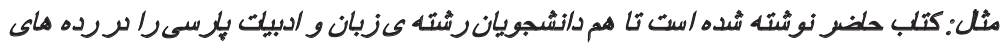



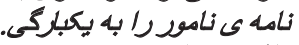

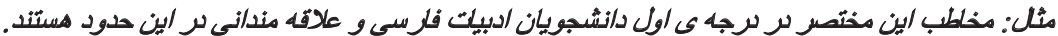

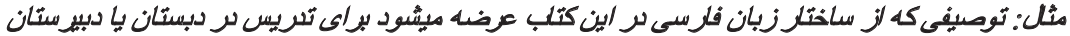

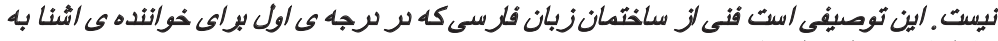

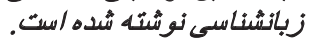

4- Description of content, book chapters and other volumes of the book:

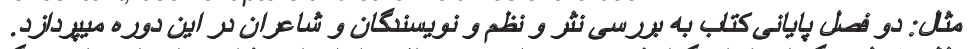

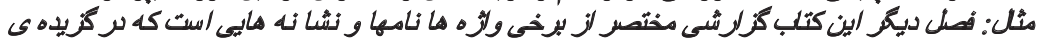

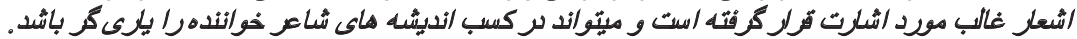

5- Generalstatement or description: 
6- Shortcomings:

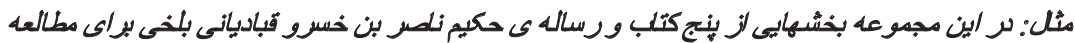
مى علاقه مندان

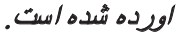

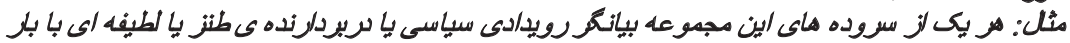

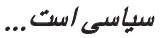

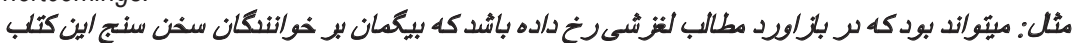

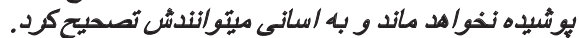

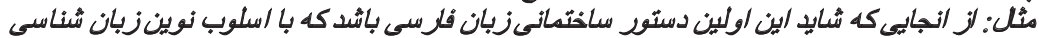

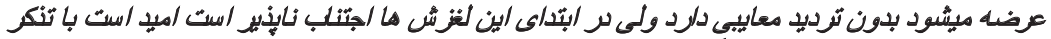

7- Acknowledgement: صاهب نظران عيوب ان برطرف تردير درد:

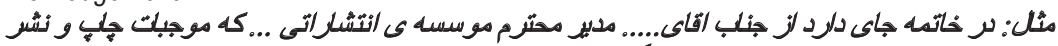

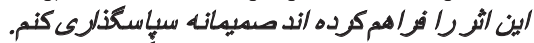

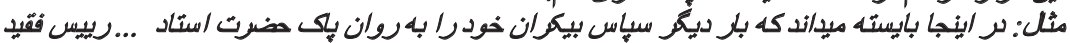

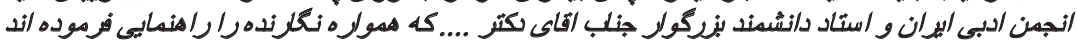

8- Expressing hope: تقديم دارد.

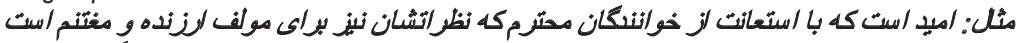

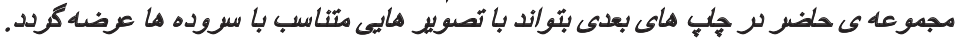

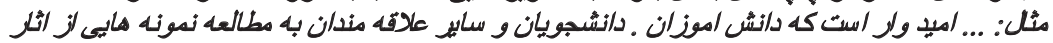

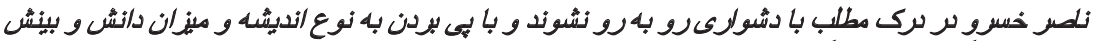

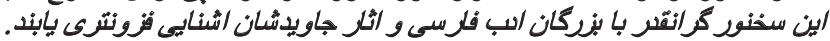

$>$ Less frequent moves: Brief explanation about previous works on the topic, explanations about signs and acronyms, and materials collection

- Explanation about previous works:

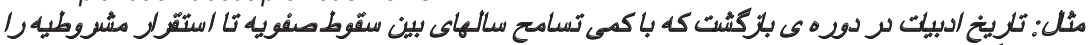

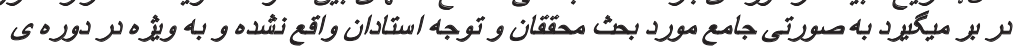



- Explanations about signs and acronyms:

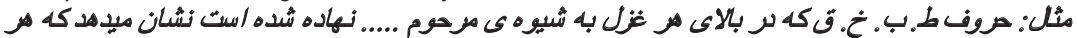

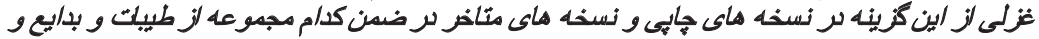

- Materials collection:

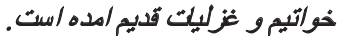

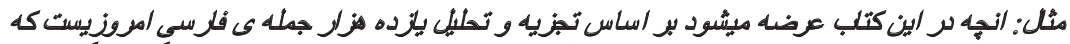

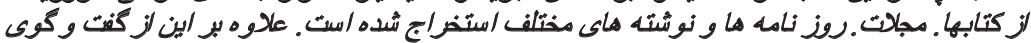

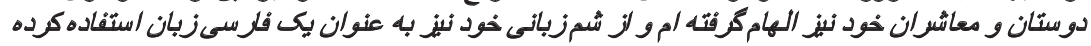

Table 2: Frequency and percentage of identified moves in Persian book prefaces

\begin{tabular}{|cl|c|c|}
\hline \multicolumn{1}{|c|}{ Move } & Frequency & Percentage \\
\hline $1-$ & Significance & 13 & $\% 65$ \\
\hline $2-$ & The purpose & 8 & $\% 40$ \\
\hline $3-$ & Type of reader & 10 & $\% 50$ \\
\hline $4-$ & Chapter description & 6 & $\% 30$ \\
\hline $5-$ & $\begin{array}{l}\text { General statement or } \\
\text { description }\end{array}$ & 16 & $\% 40$ \\
\hline $6-$ & Shortcomings & 12 & $\% 60$ \\
\hline $7-$ & Acknowledgement & 8 & $\% 40$ \\
\hline $8-$ & Hope expression & & \\
\hline
\end{tabular}

As table 2 indicates, the following moves seem to be obligatory in Persian book prefaces:

1- $\quad$ The significance of the topic 
2- General statement or description

3- (Acknowledgments) Thanking others and expressing gratitude to people who have helped in the process of writing the book

\section{Conclusion}

As the results showed, the only common main move between English and Persian book prefaces was general statement about or description of the content of the book. In both languages, the authors gave some explanations about the content in general lines. It seems that the authors of both languages are aware of the fact that providing their readers with a background will help them in better comprehension of the text. Through such general descriptions, they just try to set the scene and make the readers prepared. Beside this similarity, there were some differences between English and Persian prefaces. For example, in Persian prefaces the use of quotations from famous people and Arabic expressions were common which can show the influence of Islamic religion and culture on these authors. They also used poems to start and finish their speech. The language in Persian books was much more formal and the use of complex sentences was more frequent. Another important difference refers to the fact that the majority of Iranian writers talked about the probable shortcomings in their work and asked their readers to help them improve those shortcomings and mistakes. It can show that in Iran, the process of book publication is not that much exact and although a book is published, there may remain some errors. Moreover, although in English prefaces, the move of acknowledgment was not as frequent as it was in Persian books, in 90 percent of the books in which this move was present, a separate part was given for acknowledgement, in Persian books, it was attached to the preface. This can be an indicator that thanking others for their support is really important to English people to the extent that they express it in another separate part. But that is not the case for Iranians and they do not consider acknowledgement as an independent genre.

The findings of this study reinforce the notion that move structure of a genre may vary to some extent in different languages. It calls for more attention to the genre of preface and can be considered as an awareness- raising tool which can increase awareness of discipline- specific move structure and also prepare a discipline- specific move structure model: Explanations about the structure and content of the bEørlanations about the structure and content of the book.

The present study examined move structure of literature book prefaces in English and Persian. The corpus was of a limited size, so further research can be conducted with the same research question in a larger corpus. The move structure of the same genre can also be investigated in disciplines other than literature.

\section{References}

Afros, E., \& Schryer, C.F. (2009). The genre of syllabus in higher education. English for Specific Purposes, 8, 224-233.

Ansary, H., \& Babaii, E. (2005).The generic integrity of newspaper editorials: A systemic Functional perspective. RELC Journal, 36 (3), 271-295.

Atai, M.R., \& Fallah, S. (2005). A contrastive genre analysis of results and discussion sections of applied linguistic research articles written by native and non-native English speakers with respect to evaluated entities and ascribed values. Available online at:http:// www. Paaljapan.org/ resources/proceedings/ pAAl 10/ pdfs/ atai.pdf.

Bhatia, V.K. (1993). Analyzing genre: Language use in professional settings. London: Longman.

Biria, R., \& Tahririan, M. H. (1997). Communicative conventions in discussion discourse. International Journal of Psycholinguistics, 13 (3), 1-11.

Cross, C., \& Oppenheim, Ch. (2005). A genre analysis of scientific abstracts. Journal of Documentation, 62 (4), $428-446$.

Dudley-Evans, T. (1986). Genre analysis: An investigation of the introduction and discussion sections of MSc dissertations. LSU: University of Aston.

Golpour Lasaky, F. (2011). A contrastive study of generic organization of doctoral dissertation acknowledgments written by native and non-native (Iranian) students in applied linguistics. MJAL, 3 (2), 175-199.

Habibi, P. (2008). Genre analysis of research article introductions across ESP, Psycholinguistics, and Sociolinguistics, IJAL, 11 (2), $87-$ 111 Hüttner, J., Smith, U., \& Mehlmauer-Larcher, B. (2009). ESP teacher education at the interface of theory and practice: Introducing a model of mediated corpus-based genre analysis. System, 37, 99-109.

Halleck, G. B., \& Connor, U. M. (2006). Rhetorical moves in TESOL conference proposals. English for Specific Purposes, 5, 70-86.

Hyland, K. (2000). Disciplinary discourses: Social interaction in academic writing. London: Longman Publishing.

Henry, A., \& Roseberry, R. L. (2001). A narrow-angled corpus analysis of moves and strategies of the genre :'Letter of application'. English for Specific Purposes, 20, 153-167.

Connor, U., \& Mauranen, A. (1999). Linguistic analysis of grant proposals: European Union research grants. English for Specific Purposes, 18, 47- 62.

Dudley- Evans, T. (1994). Genre analysis: An approach to text analysis for ESP. In:Coulthard, M.(Ed.), Advances in written text analysis. Routledge, London. 
Halleck, G. B., \& Connor, U. M. (2006). Rhetorical moves in TESOL conference proposals. Journal of English for Academic Purposes, 5 , 70- 86.

Henry, A. (2007). Evaluating language learners' response to web-based, data-driven genre teaching materials. English for Specific Purposes, 26, 462-484.

Henry, A., \& Roseberry, R.L. (2001). A narrow- angled corpus analysis of moves and strategies of the genre: "letter of Application". English for Specific Purposes, 20, 153- 167.

Hyland, K. (2003). Genre- based pedagogies: a social response to process. Journal of Second Language Writing, 12, 17- 29.

Hyland, K. (2004). Graduates' gratitude: The generic structure of dissertation acknowledgments. English for Specific Purposes, 23, 303324.

Kwan, B. S. C. (2006). The schematic structure of literature reviews in doctoral theses of applied linguistics. English for Specific Purposes, 25, 30-55.

Lores, R. (2004). On RA abstracts: From rhetorical structure to thematic organization. English for Specific Purposes, 23, $280-302$.

Moreno, A. I., \& Saurez, L. (2008). A study of critical attitude across English and Spanish academic book reviews. English for Specific Purposes, 7, 15-26.

Nwogu, K.N. (1997). The medical research paper: Structure and functions. English for specific Purposes, 16, 119-138.

Ozturk, I. (2007). The textual organization of research article introductions in applied linguistics: Variability within a single discipline. English for Specific Purposes, 26, 25- 38.

Peacock, M. (2002). Communicative moves in the discussion sections of research articles. System, 30, 479- 497.

Rubio, M. (2011). A pragmatic approach to the macro-structure and metadiscoursal features of research article introductions in the field of Agricultural Sciences. English for Specific Purposes, 30, 258- 271.

Ruiying, Y., \& Allison, D. (2004). Research articles in applied linguistics: Structures from a functional perspective. English for Specific Purposes, 23, 264- 279.

Santos,P.D. (2002). Genre analysis of business letters of negotiations. English for Specific Purposes, 21, 167- 199.

Swales, J. M. (1990). Genre analysis: English in academic and research settings. Cambridge: Cambridge University Press.

Swales, J. M. (2004). Research genres: Exploration and application. Cambridge: Cambridge University Press.

Valor, M. L. G. (2005). Advertising books: A linguistic analysis of blurbs. IBERICA, 10, 41-62. 
